\title{
The importance of ultrasound findings in the study of anal pain
}

\author{
A. M. Vieira, F. Castro-Poças, P. Lago, R. Pimentel, R. Pinto, M. M. Saraiva and J. Areias \\ Department of Gastroenterology. Ultrasound Unit. Centro Hospitalar do Porto - Hospital de Santo António. Porto, \\ Portugal
}

\begin{abstract}
Objective: endoanal ultrasonography can detect organic causes of anal pain without pathology on physical examination. The aim of this study is to evaluate the importance of endoanal ultrasonography in the diagnosis and therapeutic management of idiopathic and functional anal pain.

Material and methods: retrospective study, between 15 March 2005 and 15 June 2008, of all patients with proctalgia and normal examination or with alterations not responsible for anal pain at proctologic exam that have undergone an endoanal ultrasonography.

Results: a total of 90 patients were analyzed, with a mean age of 50.5 years, $58 \%$ were female. Twenty-three patients had functional anal pain clinic criteria. Endoanal ultrasonography revealed alterations in $49 \%$ of patients. The primary findings were changes in sphincters in 14 patients, followed by anal sepsis in 12 patients, anal fissure in 10 patients, perirectal lesions in 6 patients and ulcer of the anal canal in 2 patients. Of the patients with sphincter defects, 5 patients had criteria of chronic anal pain. In this group of patients, no differences were found in manometric and defecographic results between the different ultrasound abnormalities.

Conclusions: the endoanal ultrasonography detected occult organic lesions to proctologic examination, in half the patients with anal pain. Ultrasound abnormalities were found in $22 \%$ of patients with functional anal pain. However, there was no correlation between ultrasound findings and physiological studies, and therefore could not find etiological or pathogenic factors of functional anal pain.
\end{abstract}

Key words: Anal pain. Endoanal ultrasonography. Proctalgia fugax. Chronic anal pain.

\section{RESUMEN}

Objetivo: la ecografía endoanal puede detectar causas orgánicas en el dolor anal sin patología en la exploración física. El objetivo de este estudio es evaluar la importancia de la ecografía endoanal en el diagnóstico y en el abordaje terapéutico del dolor anal idiopática y funcional.

Material y métodos: estudio retrospectivo realizado entre el 15 de marzo de 2005 y el 15 de junio de 2008, en todos los pacientes referenciados para hacerse la ecografía endoanal, debido a dolor anal con exploración física normal o sin alteraciones que justifiquen el dolor anal.

Resultados: analizamos 90 pacientes con edad media de 50,5 años, $58 \%$ mujeres. Veintitrés pacientes presentaban criterios de dolor anal funcional. La ecografía endoanal reveló alteraciones en el $49 \%$ de los casos. Las alteraciones más frecuentes fueron las alteraciones esfinterianas, en 14 pacientes, seguido de sepsis anal, en 12 pacientes, de fisura anal, en 10 pacientes, de las lesiones perirrectales, en 6 pacientes y de úlcera del canal anal, en 2 pacientes. De los pacientes con alteraciones esfinterianas, 5 pacientes tenían criterios de dolor crónico. En este grupo de pacientes, no se encuentran diferencias en los hallazgos manométricos y defecográficos entre las diferentes alteraciones ecográficas.

Conclusiones: la ecografía endoanal detectó lesiones estructurales no sospechadas en el examen físico en la mitad de los enfermos con dolor anal. Se han encontrado alteraciones ecográficas en el $22 \%$ de los pacientes con dolor anal funcional. Sin embargo, no se encontró correlación entre los hallazgos ecográficos y los estudios fisiológicos, así que no fue posible encontrar factores etiológicos o patogénicos del dolor anal funcional.

Palabras clave: Dolor anal. Ultrasonografía endoanal. Proctalgia fúgax. Dolor anal crónico.

Vieira AM, Castro-Poças F, Lago P, Pimentel $R$, Pinto $R$, Saraiva $M M$, Areias $J$. The importance of ultrasound findings in the study of anal pain. Ultrasound findings in the study of anal pain. Rev Esp Enferm Dig 2010; 102: 308-313.
Correspondence: Ana Margarida Duarte da Silva Vieira. Av. Mestre Lima de Freitas, No 411 Esquerdo. 2910-856 Setúbal, Portugal. e-mail: ana.amdsv@gmail.com 


\section{INTRODUCTION}

Anal pain can have multiple organic etiologies: gynecological, coloproctological, urogenital, neurological $(1,2)$. Although in most patients, a careful history focusing on the nature of anal pain and its relationship with fecal movements, coupled with physical examination, enables the establishment of the diagnosis, in a small fraction of patients the proctological examination does not detect any underlying disorder $(3,4)$. On the other hand, anal pain can also occur in circumstances in which organic disease is absent $(1,2,5)$. Functional anorectal pain syndromes include proctalgia fugax and chronic proctalgia, which falls in the elevator any syndrome and unspecified functional anorectal pain (6). The diagnosis is of exclusion, as it is vital to screen for other causes of anorectal pain, such as ischemia, fissures and inflammation $(1,6)$.

The study of patients with anal pain is probably one of the most difficult to assess in the field of coloproctology $(7,8)$, partly due to different causes of this symptom and the fact that sometimes the cause is more functional rather than anatomical (8). One of the most important aspects is to rule out organic disease of surgical resolution; to that end, endoanal ultrasonography offers the possibility of assessing the state and thickness of the sphincters, possible abscesses, fistulas and other perianal lesions, including endometriosis (7-11). Also in the diagnosis of hypertrophic myopathy of internal anal sphincter, a rare cause of anal pain, ultrasound detection of abnormally thickened sphincter is a key finding $(7,12,13)$. In the study of functional anal pain, endoanal ultrasonography is a fundamental tool in the exclusion of organic causes, one of the diagnostic criteria, and in the detection of ultrasound changes potentially illuminating the pathophysiology and promoting a more effective therapeutic approach $(14,15)$.

Although the study of fecal incontinence, anal sepsis and anal neoplasms constitute the main indications for endoanal ultrasonography, this test has assumed increasing importance in the search for the reasons of anal pain $(7,8,16)$.

This study aims to assess the significance of ultrasound findings in clarifying the diagnosis of anal pain of unknown etiology, to identify the percentage of cases in which endoanal ultrasound changes led to a surgical resolution; in cases clinically suggestive of functional proctalgia, to identify ultrasound abnormalities and their importance to the etiopathogenesis and treatment of functional anal pain, and correlate them with the findings of anorectal manometry and defecography.

\section{MATERIAL AND METHODS}

Retrospective analysis of patients undergoing endoanal ultrasonography for anal pain, in the period be- tween March 15, 2005 and June 15, 2008 -39 months.

Through the consultation of medical files, we excluded all patients with an identifiable cause of anal pain on physical examination. We evaluated the following variables: demographics (age and sex), previous history of anorectal disease and/or surgery, accompanying symptoms, clinical features of pain, physical examination, lower endoscopy, endoanal ultrasonography and anorectal manometry and defecography in patients with functional anal pain, therapy and evolution.

We considered the diagnosis of proctalgia fugax in cases characterized by recurrent episodes of pain localized to the anus or lower rectum, lasting seconds to minutes and symptom-free intervals in the absence of anorectal and/or pelvic disease (6). In cases of recurrent or chronic rectal pain, lasting at least 20 minutes, excluding other causes of anal pain, such as ischemia, inflammatory bowel disease (IBD), cryptitis, abscess, fissure, hemorrhoids, prostatitis and coccygodynia, the diagnosis of chronic proctalgia was established (6).

Statistical analysis was performed in Statistical Package for Social Sciences (SPSS) for Windows (version 13.0). The values of continuous variables were expressed as mean \pm standard deviation and used the Student $t$ test and Mann-Whitney test to compare averages. Categorical variables were compared by Fisher's exact test. The results were considered statistically significant to a confidence interval of $95 \%(\mathrm{p}<0.05)$.

\section{RESULTS}

In the period described, there were 652 endoanal ultrasounds, 90 of which (14\%) were due to proctalgia without organic lesions on physical examination.

\section{Demographic, epidemiological and clinical characterization}

Of the 90 patients, 52 were women (58\%) and 38 men $(42 \%)$, with a mean age of 51 years, ranging between 19 and 83 years (Table I). The mean age was similar in both sexes (50.2 vs. 50.7, $\mathrm{p}=0,887)$. The remaining data are in table I.

\section{Results of endoanal ultrasonography}

Changes were found in 44 patients (49\%), sphincter abnormalities in $14(32 \%)$, anal sepsis in $12(27 \%)$, anal fissure in $10(23 \%)$, perirectal lesions in $6(14 \%)$ and anal canal ulcer in $2(5 \%)$ (Table II). One of the cases of anal canal ulcer occurred in a patient with human immunodeficiency virus (HIV) infection and syphilis. The etiology was a Kaposi sarcoma, with gastrointestinal involvement. 
Table I. Demographic, epidemiological and clinical

\begin{tabular}{lcccc}
\hline & $n$ & $\%$ & Mean & $\begin{array}{c}\text { Standard } \\
\text { deviation }\end{array}$ \\
& & & & 14.5 \\
\hline Age (years) $(\mathrm{n}=90)$ & - & - & 50.5 & \\
Gender $(\mathrm{n}=90)$ & & & & \\
Male & 38 & 42 & - & - \\
Female & 52 & 58 & - & - \\
Origin of patients ( $\mathrm{n}=90)$ & & & & \\
Gastroenterology & 60 & 66 & - & - \\
Surgery & 16 & 18 & - & - \\
Another hospital & 9 & 10 & - & - \\
Another department & 5 & 6 & - & - \\
Associated diseases & 15 & 17 & - & - \\
IBD & 10 & 66 & - & - \\
Neurological disease & 3 & 20 & - & - \\
Vulva neoplasm & 1 & 7 & - & - \\
Abdominal endometriosis & 1 & 7 & - & - \\
Previous anorectal disease & 32 & 36 & - & - \\
Previous anorectal surgery & 22 & 24 & - & - \\
Accompanying symptoms & 21 & 23 & - & - \\
Dyschezia & 8 & 38 & - & - \\
Pruritus ani & 4 & 19 & - & - \\
Rectorrhagy & 4 & 19 & - & - \\
Perianal tumefaction & 3 & 14 & - & - \\
Constipation & 3 & 14 & - & - \\
Soiling & 1 & 5 & - & - \\
Tenesmus & 1 & 5 & - & - \\
Dyspareunia & 1 & 5 & - & - \\
Diarrhea & 1 & 5 & - & - \\
Lower gastrointestinal endoscopy & 64 & 44 & - & - \\
Normal & 39 & 61 & - & - \\
Polyps & 14 & 22 & - & - \\
IBD & 9 & 14 & - & - \\
Tumefaction of the rectal wall & 1 & 2 & - & - \\
Staple and mucosal inflammation & 1 & 2 & - & - \\
Proctologic examination ( $\mathrm{n}=90)$ & & & & \\
Normal & 44 & 49 & - & - \\
Anal tags & 32 & 36 & - & - \\
Internal hemorrhoids grade 1 & 14 & 15 & - & - \\
\hline
\end{tabular}

Table II. Results of endoanal ultrasonography

\begin{tabular}{lccc}
\hline Results of ultrasonography & $\begin{array}{c}\text { Patients with } \\
\text { functional } \\
\text { anal pain (n/\%) } \\
n=23\end{array}$ & $\begin{array}{c}\text { Patients with anal } \\
\text { pain not otherwise } \\
\text { specified (n/\%) } \\
n=67\end{array}$ & Total (n/\%) \\
\hline Normal & $18 / 78$ & $28 / 42$ & $n=90$ \\
Abnormal & $5 / 22$ & $39 / 58$ & $46 / 51$ \\
Sphincter changes & $5 / 100$ & $9 / 23$ & $14 / 32$ \\
Anal sepsis & & $12 / 31$ & $12 / 27$ \\
Anal fissure & & $10 / 26$ & $10 / 23$ \\
Perirectal lesions & & $6 / 15$ & $6 / 14$ \\
Anal canal ulcer & & $2 / 5$ & $2 / 5$ \\
\hline
\end{tabular}

Of the patients with sphincter changes, 6 showed increased thickness of the internal anal sphincter (IAS), 2 atrophy of the IAS, 2 echo texture changes of the IAS, 3 echo texture changes of the external anal sphincter (EAS), 2 lacerations of the EAS and 1 laceration of the
IAS. One patient had concomitant laceration of the EAS and echo texture changes of the IAS, and other IAS atrophy and EAS echo texture changes.

The group of patients with anal sepsis included 5 cases of fistula with abscess, 3 fissures with abscess, 2 abscesses (Fig. 1) and 2 fistulas. Only one patient with anal sepsis had IBD history.

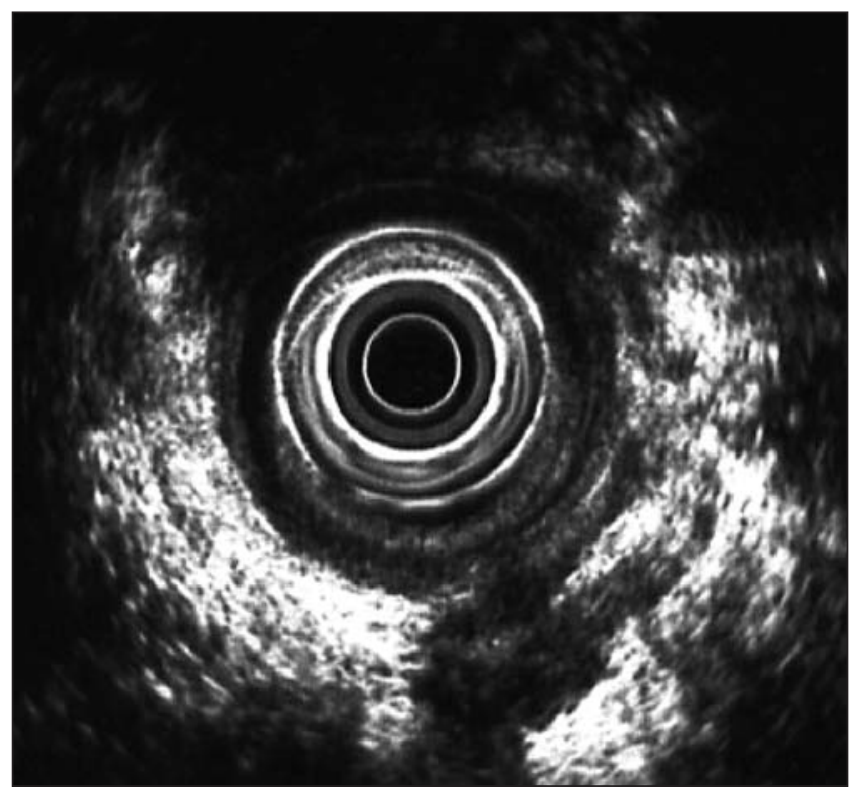

Fig. 1. Abscess in the supraelevator space.

Among the 6 patients with perirectal lesions we diagnosed perianal endometriosis in 3 patients, basal cell carcinoma (retrovaginal heterogeneous nodular lesion) in one patient and prostatic calculi (prostatic solid calcified lesion) in another patient. The last patient had a heterogeneous perirectal area for which a definitive diagnosis could not be provided. The cystic lesion in the ischioanal space (Fig. 2), heterogeneous lesion in the rectovaginal septum (Fig. 3) and heterogeneous perirectal lesion with extension to the rectal wall were the ultrasonographic aspects of endometriosis. It should be noted that the diagnosis of perianal endometriosis was histologically confirmed in all cases, and none of the patients had a history of endometriosis. Finally, we emphasize that the patient with a diagnosis of basal cell carcinoma had a previous surgical intervention due to vulvar cancer.

\section{Analysis of patients with functional anal pain}

Of the 90 patients studied, 23 had clinical criteria of functional anal pain, 7 with proctalgia fugax and 16 with chronic anal pain. Eighteen patients $(78 \%)$ were female and the average age was $53 \pm 11$, ranging from ages 25 to 66 . 


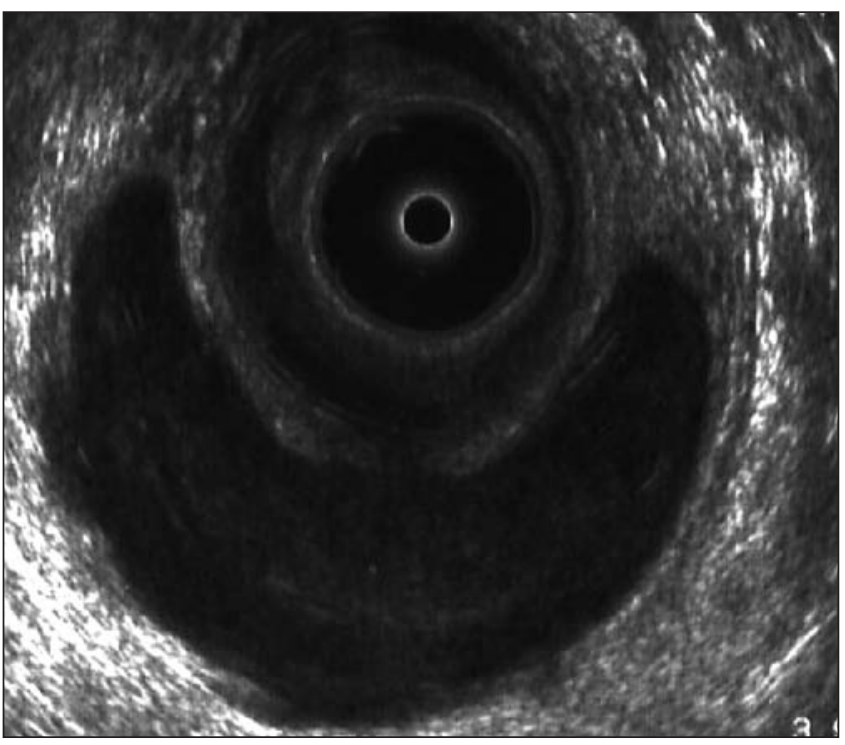

Fig. 2. Cystic lesion in the ischioanal space - endometriosis.

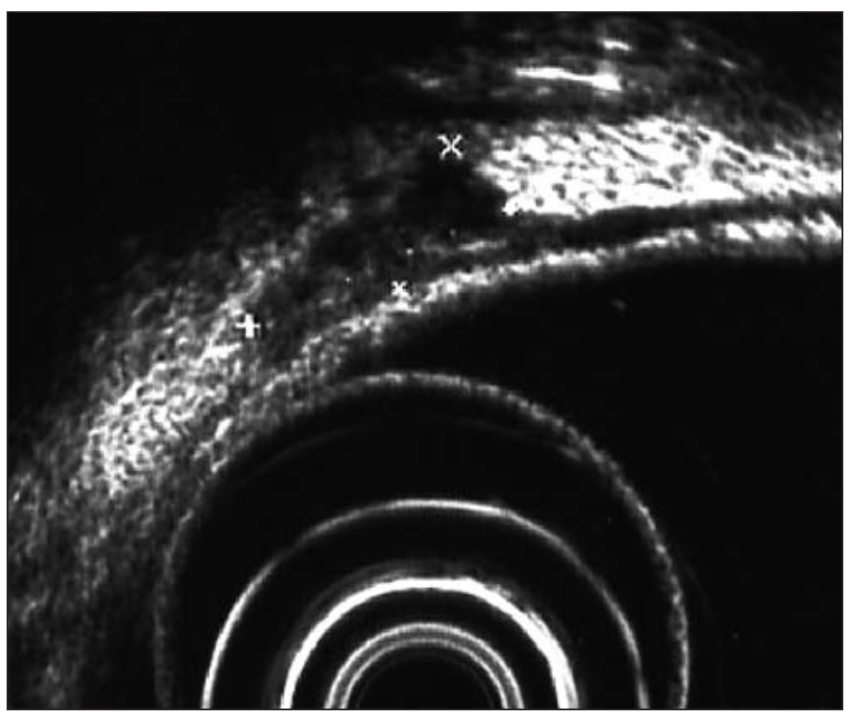

Fig. 3. Heterogeneous lesion in the rectovaginal septum -endometriosis.

Only 5 patients $(22 \%)$ had ultrasound changes (Table II): IAS thickening -2 patients (mean value $3,35 \mathrm{~mm}$ )-; IAS atrophy -2 patients (mean value $0,85 \mathrm{~mm}$ )-; and echo texture changes of the EAS -2 patients. One patient presented concurrent IAS atrophy and ultrasound changes of the EAS. We should point out the absence of previous anorectal disease or surgery in the 5 patients.

All patients underwent anorectal manometry and defecography. Some patients had more than one change at the same time, both in anorectal manometry and defecography. Tables III and IV provide a breakdown of the changes found.
Table III. Results of anorectal manometry in patients with functional proctalgia

\begin{tabular}{|c|c|c|}
\hline & $n$ & $\%$ \\
\hline Normal & 9 & 39 \\
\hline Abnormal & 14 & 61 \\
\hline Chronic anal pain $(\mathrm{n}=16)$ & 10 & 62 \\
\hline RS decreased & 7 & - \\
\hline RP decreased & 3 & - \\
\hline VC decreased & 2 & - \\
\hline RP increased & 1 & - \\
\hline Proctalgia fugax $(n=7)$ & 4 & 57 \\
\hline RS decreased & 2 & - \\
\hline Ultraslow waves & 2 & - \\
\hline VC decreased & 1 & - \\
\hline RS increased & 1 & - \\
\hline
\end{tabular}

RS: rectal sensitivity; RP: resting pressure of the anal canal; VC: voluntary contraction.

Table IV. Results of defecography in patients with functional proctalgia

\begin{tabular}{lcc}
\hline & $n$ & $\%$ \\
\hline Normal & 12 & 52 \\
Abnormal & 11 & 48 \\
$\quad$ Chronic anal pain $(\mathrm{n}=16)$ & 9 & 56 \\
Perineal descent & 8 & - \\
Rectocele & 4 & - \\
Dyssynergia & 1 & - \\
$\varnothing$ puborectalis relaxation & 1 & - \\
Proctalgia fugax $(\mathrm{n}=7)$ & 2 & 29 \\
Perineal descent & 1 & - \\
Rectocele & 1 & - \\
\hline
\end{tabular}

Ø: absence.

\section{Additional analysis of results}

We evaluated the relationship between cases of anal sepsis and IBD history and could find no statistical association (1/12 vs. 9/77, $\mathrm{p}=1.000)$. Likewise, no association was found between ultrasonographic changes of the sphincters and history of anorectal disease $(5 / 14 v s .27 / 76, \mathrm{p}=1.000)$ and/or surgery $(2 / 14 v s .20 / 76, \mathrm{p}=0.503)$ or a history of a given disease, including neurological diseases $(2 / 14 \mathrm{vs}$. $1 / 76, p=0.062)$. Nor were sphincter changes associated with the presence of specific symptoms and concomitant dyschezia $(1 / 14 v s .7 / 76, \mathrm{p}=1.000)$ or chronic anal pain $(4 / 14 v s .12 / 76, \mathrm{p}=0.264)$.

For patients with functional anal pain, we did not find a specific manometric pattern for proctalgia fugax and chronic anal pain $(\mathrm{p}=0,232)$, and there was, in general, a tendency for anorectal hyposensitivity, hypomotility and hyporeactivity $(56.5 \%)$. There were no defecographic differences between the two diseases $(2 / 7 v s .9 / 16, \mathrm{p}=$ $0.371)$.

We found manometric and defecographic alterations in patients without ultrasound changes, and one patient showing increased thickness of the IAS $(3.5 \mathrm{~mm})$ had no anorectal manometric changes. 
In the analysis of the relationship between endoanal ultrasonography and functional tests, there was no correlation between manometric and defecographic findings and the different ultrasound abnormalities $(\mathrm{p}=1.000)$.

\section{DISCUSSION}

The idiopathic proctalgia represented $14 \%$ of the indications for endoanal ultrasonography, a higher percentage than that described in literature. In the Italian multicenter study, anal pain was an indication for this exploration between 0 and $13.2 \%$ (17). When analyzing the Chilean group, anal pain was, in $7.3 \%$ of cases, the reason for performing an endoanal ultrasound (8).

Pascual et al. demonstrated a high diagnostic yield of endoanal ultrasonography in the study of anal pain, by identifying the cause of anal pain in $82 \%$ (77/95) of cases (13). In our series, endoanal ultrasonography revealed changes in 44 patients (49\%); identified specific organic disease (fissures, fistulas and/or abscesses, anal ulcers and perianal endometriosis, vulvar basal cell carcinoma and prostatic calculi) in 29 patients (32\%). In these cases, the endoanal ultrasonography determined a specific therapeutic approach that was surgical intervention in 13 cases $(14 \%)$. Endoanal ultrasonography was, therefore, decisive for the evolution of these patients.

Except for perirectal lesions, the remaining changes (fistulas/abscesses in 12 patients, anal fissure in $10 \mathrm{pa}$ tients and anal canal ulcer in 2 patients) are usually identified on physical examination. Probably the pain associated with these conditions may have constituted the main limitation of physical examination. Furthermore, we underline that the abscessed processes were deeply located in the ischioanal and supraelevator spaces. It should also be mentioned the possible error inherent to the study methodology: it is a retrospective study, whose physical examination data were collected through the consultation of medical files, and the proctological examinations were performed by different physicians, with distinct levels of training in coloproctology.

For perirectal lesions, experience, availability and rapid response from the Ultrasound Sector showed that these diagnoses were established by endoanal ultrasound, at the expense of other imaging methods. We emphasize the significant ratio of perirectal causes of anal pain $(6.7 \%)$ namely of perianal endometriosis (3.3\%), which once again shows the importance of the endoanal ultrasonography in the clinical management of these patients.

In the study by López-Köstner et al., of the 73 patients who underwent endoanal ultrasonography for clarification of idiopathic anal pain, organic pathology was detected in 23 patients $(31.5 \%)$; anal sepsis in 15 patients $(20.5 \%)$, perineal tumors in 8 patients $(11 \%)$, of which $5.5 \%$ were cases of perianal endometriosis; these results were similar to those in our study (8).
The "varied combination of recurrent or chronic gastrointestinal symptoms unexplained by structural or biochemical abnormalities" is a narrow definition of functional gastrointestinal disorders (18). In fact, the problem is more complex. We currently have sophisticated tools that can characterize the structure and anorectal function that show structural and functional changes in patients with disorders considered "idiopathic" or "functional" (6). The distinction between "organic" and "functional" may be difficult to make because: a) the causal relationship between structural abnormalities and anorectal function may be unclear, because such abnormalities are often observed in asymptomatic subjects (e.g., small anal sphincter defects); b) organic lesions are influenced by behavioral adaptations; and c) patients may have several structural or functional disorders, each of which may contribute to but cannot solely explain symptoms (6).

In our study, we found sphincter ultrasound changes in 5 patients with chronic anal pain (22\%). However, the functional and clinical significance of these changes remains unexplained because we were unable to establish a correlation between anatomical changes and the results of functional studies.

Likewise, in a prospective study of 18 patients with chronic anal pain who underwent physiological and histopathologic evaluation using physiologic studies, defecography, endoanal ultrasonography and sphincter biopsy, Christiansen et al. found ultrasound changes in 12 patients $(67 \%)$. However, no correlation was found between ultrasound and physiological changes and histological defects or response to treatment with biofeedback or botulinus toxin (14).

In a controlled study of 12 patients with chronic anal pain, anorectal manometry showed a significant increase of anal resting pressure and a clear benefit from using biofeedback (19). In contrast, in our study, the main manometric findings included decreased rectal sensitivity (44\%) and anal resting pressure (19\%), a situation that is most often associated with fecal incontinence (20). In fact, several studies show that patients with chronic anal pain usually show increased anal resting pressure and the electromyographic activity and pain relief is associated with a decrease of resting pressure $(2,5)$. However, it is also true that the importance of anorectal manometry in the evaluation of these patients is questionable $(2,5)$. Their interpretation is complicated by the fact that patients are able to compensate for deficits in specific physiological mechanisms by utilizing other biological and behavioral mechanisms (20).

During defecography, $50 \%$ of patients with chronic anal pain had perineal descent. Similarly, Neill and Swash, and Salzano and colleagues found 81 and $26 \%$ of perineal descent in patients with chronic anal pain, respectively $(21,22)$.

With regard to proctalgia fugax, different pathophysiological mechanisms have been considered: spasm of the IAS $(23,24)$, pudendal neuralgia $(25)$, anal paroxysmal 
hyperkinesia (26), myopathy of the IAS $(27,28)$ and psychological factors (29), but its pathogenesis remains unknown.

In a prospective study with 15 patients with proctalgia fugax, 5 patients (33\%) had hypertrophy of the IAS (15). However, these results have not been corroborated in the controlled study of Eckart et al., in which no changes in the thickness of the sphincter were found (23). No ultrasound changes were found in our study, either.

In conclusion, endoanal ultrasonography revealed changes in approximately half the patients with proctalgia of unknown etiology; allowed a definitive diagnosis in $32 \%$ of cases with specific therapeutic implications, while leading to a surgical approach in $14 \%$. These results reflect the importance of endoanal ultrasonography in clarifying anal pain, thus allowing for the diagnosis of unsuspected organic lesions on physical examination and, therefore, the authors argue that this examination should be part of the diagnostic approach of idiopathic anal pain on physical examination.

The etiopathophysiological and clinical importance of sphincter ultrasound changes, and its correlation with the function of anal sphincters remain unexplained. For this reason, the main utility of endoanal ultrasonography in the evaluation of suspected functional anal pain is to exclude organic diseases.

\section{REFERENCES}

1. Cheung O, Wald A. Review: management of pelvic floor disorders. Aliment Pharmacol Ther 2004; 19: 481-95.

2. Mazza L, Formento E, Fronda G. Anorectal and perineal pain: new pathophysiological hypothesis. Tech Coloproctol 2004; 8: 77-83.

3. Pfenninger JL, Zainea GG. Common anorectal conditions: Part I. Symptoms and complaints. Am Fam Physician 2001; 63: 2391-8.

4. Felt-Bersma RJF, Cazemier M. Endosonography in anorectal disease: an overview. Scan J Gastroenterol 2006; 41(Supl. 243): 165-74.

5. Wald A. Functional anorectal and pelvic pain. Gastroenterol Clin North Am 2001; 30(1): 243-51.

6. Bharucha AE, Wald A, Enck P, Rao S. Functional anorectal disorders. Gastroenterology 2006; 130: 1510-8.

7. Kumar A, Scholefield JH. Endosonography of the anal canal and rectum. World J Surg 2000; 24(2): 208-15.

8. López-Köstner F, Zárate AC, Garcia-Huidobro MD, Pinedo GM, Molina MP, Krönberg U, et al. Indications and results of the endoluminal ultrasonography. Rev Chilena de Cirugía 2007; 59: 31-7.

9. Saranovic D, Barisic G, Krivokapic Z, Masulovic D, Djuric-Stefanovic A. Endoanal ultrasound evaluation of anorectal diseases and disorders: technique, indications, results and limitations. Eur J Radiol
2007; 61: 480-9.

10. Hernández-Magro PM, Sáenz EV, Fernández FA-T, Rámirez JLR, Ovalle MV. Endoanal sonography in the assessment of perianal endometriosis with external anal sphincter involvement. J Clin Ultrasound 2002; 30: 245-8.

11. Toyonaga T, Matsushima M, Tanaka Y, Nozawa M, Sogawa N, Kanyama H, et al. Endoanal ultrasonography in the diagnosis and operative management of perianal endometriosis: report of two cases. Tech Coloproctol 2006; 10: 357-60.

12. Martorell P, Azpiroz F, Malagelada JR. Hypertrophic myopathy of the internal anal sphincter: a rarely recognized cause of proctalgia. Rev Esp Enferm Dig 2005; 97: 527-9.

13. Pascual I, García-Olmo D, Martínez-Puente C, Pascual-Montero JA Ultrasound findings in spontaneous and postoperative anal pain. Rev Esp Enferm Dig 2008; 100: 764-7.

14. Christiansen J, Bruun E, Skjoldbye B, Hagen K. Chronic idiopathic anal pain: analysis of ultrasonography, pathology, and treatment. Dis Colon Rectum 2001; 44: 661-5.

15. Gracia Solanas JA, Ramírez Rodríguez JM, Elía Guedea M, Aguile1la Diago V, Martínez Díez M. Sequential treatment for proctalgia fugax. Mid-term follow-up. Rev Esp Enferm Dig 2005; 97: 491-6.

16. Rottenberg GT, Williams AB. Endoanal ultrasound. Br J Radiol 2002; 75: 482-8.

17. Whitehead WE, Wald A, Diamant NE, Enck P, Pemberton JH, Rao SSC. Functional disorders of the anus and rectum. Gut 1999; 45(Supl. II): II55-II59.

18. Deen KI, Kumar D, Williams JG, Olliff J, Keighley MRB. Anal sphincter defects correlation between endoanal ultrasound and surgery. Ann Surg 1993; 218: 201-5.

19. Grimaud J-C, Bouvier M, Naudy B, Guien C, Salducci J. Manometric and radiologic investigations and biofeedback treatment of chronic idiopathic anal pain. Dis Colon Rectum 1991; 34: 690-5.

20. Azpiroz F, Enck P, Whitehead WE. Anorectal functional testing: review of collective experience. Am J Gastroenterol 2002; 97: 232-40.

21. Neill ME, Swash M, Chronic perianal pain: an unsolved problem. J R Soc Med 1982; 75: 96-101.

22. Salzano A, Carbone M, Rossi E, De Rosa A, Muto M, Amodio F, et al. Defecography and treatment of essential anal pain. Radiol Med (Torino) 1999; 98: 48-52.

23. Eckardt VF, Dodt O, Kanzler G, Barnhard G. Anorectal function and morphology in patients with sporadic proctalgia fugax. Dis Colon Rectum 1996; 39: 755-62.

24. Sánchez Romero AM, Arroyo Sebastián A, Pérez Vicente FA, Serrano Paz P, Candela Polo F, Calpena Rico R. Treatment of proctalgia fugax with botulinum toxin: results in 5 patients. Rev Clin Esp 2006; 206: $137-40$

25. Takano M. Proctalgia fugax: caused by pudendal neuropathy? Dis Colon Rectum 2005; 48: 114-20.

26. Rao SSC, Hatfield RA. Paroxysmal anal hyperkinesis: a characteristic feature of proctalgia fugax. Gut 1996; 39: 609-12.

27. Celik AF, Katsinelos P, Read NW, Khan MI, Donnelly TC. Hereditary proctalgia fugax and constipation: report of a second family. Gut 1995; 36: 581-4

28. Martorell P, Azpiroz F, Malagelada JR. Hypertrophic myopathy of the internal anal sphincter: a rarely recognized cause of proctalgia. Rev Esp Enferm Dig 2005; 97: 527-9.

29. Renzi C, Pescatori M. Psychologic aspects in proctalgia. Dis Colon Rectum 2000; 43: 535-9. 